\title{
HYDROGEOLOGICAL CONDITIONS AND GROUNDWATER QUALITY IN VAGIA BASIN (VIOTIA/GREECE)
}

\author{
Stamatis G. ${ }^{1}$, Davou I. ${ }^{1}$, Hermides D. ${ }^{1}$ and Karavitis C. ${ }^{1}$ \\ ${ }^{1}$ Agricultural University of Athens, Department of Natural Resources Management and \\ Agricultural Engineering, 11855 Athens, Greece, stamatis@aua.gr,eirini@live.co.uk, \\ ckaravitis@aua.gr,dermides@aua.gr
}

\begin{abstract}
This study refers to hydrogeological conditions that dominate in the closed basin of Vagia of Viotia with emphasis on groundwater quality. It highlights the environmental problem of the region, associated with floods, phenomenon which occurs every year and lasts throughout the wet season. This, results in flushing undesirable substances from the territories of intensely cultivated area and the penetration into the groundwater of Neogene- Quaternary and carbonates aquifers. Qualitative charge of groundwater is reflected in the high concentrations of the ions $N a^{+}: 22,2-133,4 \mathrm{mg} / \mathrm{l}$, $\mathrm{K}^{+}: 0,3-12,0 \mathrm{mg} / \mathrm{l}, \quad \mathrm{SO}_{4}^{2-}: 2,1-68,9 \mathrm{mg} / \mathrm{l}, \quad \mathrm{Cl}: 24,8-241,1 \mathrm{mg} / \mathrm{l}, \quad \mathrm{NO}_{3}: 13,6-67,0 \mathrm{mg} / \mathrm{l}$, $\mathrm{NH}_{4}{ }^{+}: 0,01-1,75 \mathrm{mg} / \mathrm{l}, \mathrm{PO}_{4}{ }^{3-}: 0,03-0,94 \mathrm{mg} / \mathrm{l}$ as well as the strong presence of heavy metals (Fe, $\mathrm{Mn}, \mathrm{Zn}, \mathrm{Ni}, \mathrm{Co}, \mathrm{Cu}$ and $\mathrm{Cr}$ ). Qualitative charge of groundwater is attributed to natural (geogenic) and anthropogenic factors.
\end{abstract}

Keywords: Hydrogeology, Groundwater Quality, Water Degradation.

\section{Пєрí}

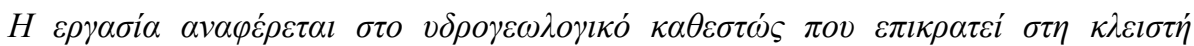

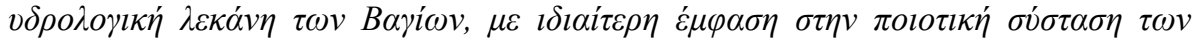

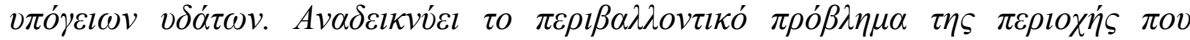

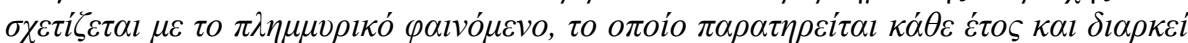

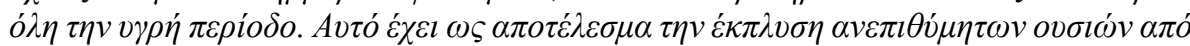

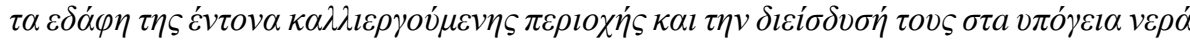

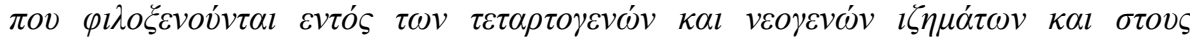



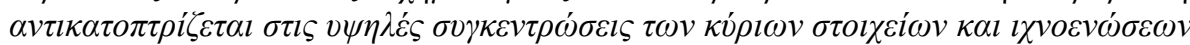
$\mathrm{Na}^{+}: 22,2-133,4 \mathrm{mg} / \mathrm{l}, \quad \mathrm{K}^{+}: 0,3-12,0 \mathrm{mg} / \mathrm{S} \quad \mathrm{SO}_{4}{ }^{2}-2,1-68,9 \mathrm{mg} / \mathrm{l}, \quad \mathrm{Cl}: 24,8-241,1 \mathrm{mg} / \mathrm{l}$,

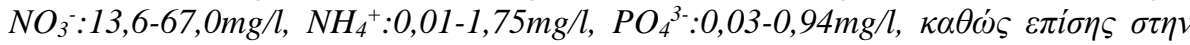

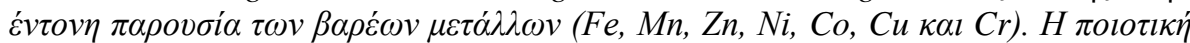

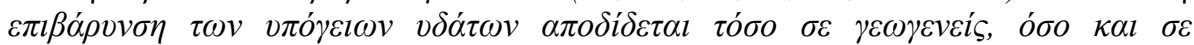
$\alpha \nu \theta \rho \omega \pi \sigma \gamma \varepsilon v \varepsilon i ́ \varsigma \pi \alpha \rho \alpha ́ \gamma o v \tau \varepsilon \varsigma$.

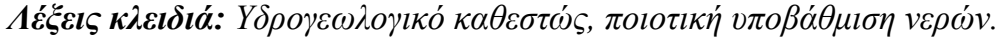

\section{Introduction}

Vagia basin is extension of Thiva basin to the west. It is of special hydrological-hydrogeological interest as it is closed hydrological basin resulting rainwater to accumulate and overwhelm an important part of the plain during wet season. This situation creates serious problems in the intensively cultivated plain, with corresponding effects on the economy of the region. To reduce the 
volume of runoff, two artificial projects were constructed, in the south-east and north-west region. In the southeastern hilly region, the surface waters from the slopes are collected in a channel and they are diverted to the stream Kanavari, flowing through the basin of Thebes, towards Yliki Lake. The northwestern channel was constructed at the foot of the Sfiga Mt. and it drains part of surface water flooding the northwest part of the valley. The surface waters are diverted to Kopais basin through a pumping system because of the altitude difference between Vagia and Kopais basin. This pumping system is out of order at the present time and it cannot discharge the accumulated surface water and soil drainage water, contributing to the appearance eutrophic conditions in the channel. A significant volume of water floods the plains of the basin throughout the period of the wet season. Inorganic and organic chemical compounds of natural and anthropogenic origin wash out from the territories of the region and they are transferred through the infiltration into aquifers, resulting in their qualitative degradation. In this study, geological, hydrogeological and hydrochemical characteristics of the area are presented. The purpose of the survey is to highlight the problem of the region and the serious impact on the quality of groundwater, which is heavily exploited in order to satisfy irrigation and water supply needs.

\section{Study area}

The study area is a closed hydrological basin which extends between the basin of Thebes in the east and the basin of Copais to the west (Fig. 1). The biggest part of the above area is the Vagia basin that extends to elevation between 90 and 100 amsl. In the south of Vagia basin appear hilly elevations (Megali Rachi $300 \mathrm{~m}$ ) while to the north, east and west appear mountainous.



Figure 1 - Geological map of study area and the points of groundwater sampling.

The highest mountains in the region are the Sfiga Mt. to the north $(620 \mathrm{~m})$ and Patima Mt. northeast $(350 \mathrm{~m})$. These hilly elevations delimit the physical boundaries Vagia's closed basin. The geological structure of the above area consists of lithological formations deposited during Cenozoic era (Neogene- Quaternary) (younger) and during the Mesozoic era (Upper Triassic-Jurassic-Cretaceous) (older formations). The underlying formations belong to the wider zone of Eastern Greece characterized by layers deposited continually during Cenomanian transgression up to Eocene. The south hilly area and the basin of Vagia are made up by two groups of post-alpine sediments. At the 
top, loose formations of Pleistocene and Holocene sediments occur, while Pleistocene sediments are probably represented at some depth. The Pleistocene is represented by lacustrine and torrential sediments mainly clays, marls, sandstone, gravels and pebbles and the Pliocene by mainly lagoon sediments. These materials come from the erosion of carbonate, flysch and shale-chert formation of the area which is at the margin of the basin. The thickness of the neogene sediments, in the central part of the basin, is over than $100 \mathrm{~m}$. The mountainous masses consist of Triassic-Jurassic carbonate rocks which are folded, intensively tectonic stressed and karstified. The carbonates are medium to thin-bedded, microcrystalline and bituminous and the thickness of them is hundreds of meters. The shale-chert formation (Lower Jurassic) conformation occupies a small area in the northern part of the region and consists of clays, sandstones, conglomerates, cherts and ophiolites serpentines. The thickness of it is tens of meters. Vagia basin is a neotectonic graben which formed in the Tertiary period. For many faults, the direction of the strike is towards of NE-SW, NW-SE and E-W. Characteristic of the geological structure of the region is the up thurst of Jurassic limestone over the formations of the whole complex of the Eastern Greece zone (Tataris et al., 1970).

\section{Hydrology}

The area of Vagia is a closed hydrological basin $67 \mathrm{~km}^{2}$ which occupies the central part of the prefecture of Viotia and extends between the basin of Kopais in NE and the basin of Thiva eastwards. $30 \mathrm{~km}^{2}$ of the above area are irrigated. Climate is a typical Mediterranean, with average annual temperature of $16.9^{\circ} \mathrm{C}$ and mean annual precipitation $485 \mathrm{~mm}$ (average value of adjacent rainfall stations 1980-2001 Aliartos: $544 \mathrm{~mm}$, Thisvi: $433 \mathrm{~mm}$ and Kalithea: $474 \mathrm{~mm}$, (Hellenic National Meteorological Service). Precipitation on the basin is $32.5 * 10^{6} \mathrm{~m}^{3}$. Supposing that evapotranspiration is about $65 \%$, the volume of water corresponding to the evaporation is about $21.1 * 10^{6} \mathrm{~m}^{3}$. Based on the extent of geological formations in the area and the average values of infiltration (carbonates $22.1 \mathrm{~km}^{2}$ and $40 \%$ infiltration, alluvium $28.74 \mathrm{~km}^{2}$ and $15 \%$ infiltration, Pliopleistocene deposits $14.5 \mathrm{~km}^{2}$ and $13 \%$ infiltration and shales-cherts $1.5 \mathrm{~km}^{2}$ and $5 \%$ infiltration) the estimated volume of total infiltration is $7.4 * 10^{6} \mathrm{~m}^{3}$. The surface water volume is $4 * 10^{6} \mathrm{~m}^{3}$ and corresponds to $11 \%$ of precipitation. In the north-eastern part of Vagia community has built an artificial channel, through which surface water of about $1 * 10^{6} \mathrm{~m}^{3}$, is discharged to the torrent Kanavari flowing through the basin of Thiva. This artificial channel contributes to reducing the volume of surface water, which is concentrated in the lowest topographic area of Vagia valley and covers the northwest part of the valley between the Sfiga Mt. and the provincial road of ThivaLevadeia. Surface waters stagnate in this part of the plain with negative effects, both on crops and quality degradation of groundwater, due to transport of pollutants (fertilizers, pesticides, etc.) from the territories of the region. The largest volume of stagnant water drains through a sinkhole located at the foot of the Sfiga Mt. (Figure 1), while the rest infiltrates into the loose formations. Obviously, a percentage of this water is transferred to the karstic formations.

\section{Hydrogeology}

In the study area there two groups of rocks with distinguished hydrogeological characteristics such as mechanism of groundwater flow and potential of aquifer. The first group includes granular formations as alluvial deposits and Plio-Pleistocene sediments while the second group comprises limestone and shale-chert formation. An upper unconfined aquifer exists in the loose Neogene Quaternary sediments showing in places confined conditions. Deep wells were tapped this upper system in the past while nowadays deep irrigation boreholes exist. In deeper layers, intensively karstified carbonates rocks exist showing a rich karstic aquifer which discharges in the Yliki Lake and in the coast of north Evoikos Gulf. The thickness of the Neogene-Quaternary sediments is over a hundred meters and show varied composition, as a result the aquifers exhibit anisotropy on both the horizontal and vertical plane. In the northern plains of the basin, alluvium deposits overlay the autochthonous carbonate rocks, resulting in a hydraulic connection between these two individual aquifers. Conversely, in the southern part the underlying formations of alluvium are the Plio- 
Pleistocene deposits; so aquifer is poor. Most of the boreholes reach the depth of $150 \mathrm{~m}$ and exploit the upper and the lower aquifers at a time. Discharged rate from drilled wells, in the upper aquifer, ranges between 30 and $40 \mathrm{~m}^{3} / \mathrm{h}$ with high drawdown and very low specific capacity. Conversely, discharged rate from drilled wells in the karstic aquifer is higher than a $100 \mathrm{~m}^{3} / \mathrm{h}$. The total number of the boreholes is over 200. Two of these wells located northern of the municipality Vagia cover the water needs of residents. Piezometric level is the same (both in upper and lower aquifer) and ranges between 65 and $70 \mathrm{~m}$ amsl (Pagounis et al., 1980). Groundwater flow in the central plain of the basin has a principal direction from SE to NW of the basin, where discharges in the carbonate mass at the foot of Sfiga Mt. In southern parts of the basin, the groundwater flow direction is towards south. An important role in differentiating the groundwater flow is the tectonic structure of the region. Recharge of the upper aquifer is derived from precipitation. Recharge of the lower aquifer comes from both precipitation and lateral inflow from Neogene- Quaternary deposits.

\section{Materials and Methods}

In order to monitor the quality of groundwater, water sampling was held in 18 boreholes $100-300$ $\mathrm{m}$ deep and 3 springs, in August 2012. In situ, temperature $\left(\mathrm{T}{ }^{\circ} \mathrm{C}\right.$ ), electrical conductivity (EC $\mu \mathrm{S} / \mathrm{cm})$, $\mathrm{pH}$ were measured using the gauges WTW/LF330/SET and WTW/330i. Ions $\mathrm{Ca}^{2+}, \mathrm{Mg}^{2+}$, $\mathrm{Na}^{+}, \mathrm{K}^{+}, \mathrm{HCO}_{3}{ }^{-}, \mathrm{Cl}^{-}, \mathrm{SO}_{4}{ }^{2-}, \mathrm{NO}_{3}{ }^{-}, \mathrm{NH}_{4}{ }^{+}, \mathrm{PO}_{4}{ }^{3-}$, heavy metals $\mathrm{Cd}, \mathrm{Co}, \mathrm{Cu}, \mathrm{Fe}, \mathrm{Mn}, \mathrm{Ni}, \mathrm{Pb}, \mathrm{Cr}$ tot $\mathrm{Zn}$ total and carbonate hardness were analyzed in the laboratory of Mineralogy and Geology in Agricultural University of Athens, using the methods of titration, spectrophotometry (HACK, DR/3000), flame photometry (Flame photometer INTECH/420) and atomic absorption (GBC/908AAS). Sampling and analyses were conducted to investigate the quality of groundwater in Vagia basin and to interpret the geogenic and anthropogenic origin of the chemical elements (Davou 2014). Table 1 presents the results of chemical analyses.

\section{Groundwater Quality}

The composition of groundwater in Vagia basin varies widely. Figure 2 shows the average values of the main elements from Quaternary, Neogene and carbonate aquifers. The biggest variation was found in groundwater of Plio-Pleistocene and Quaternary sediments. This phenomenon is evidence of coexistence water in the natural replenishment area and water affected mainly by anthropogenic factors. These waters are located in boreholes of the flat part of the basin, where the cultivation is intense. The waters are characterized by wide variation of concentration of salts (TDS:580-974mg/l), high hardness values (TH:16,0-32,0 ${ }^{0} \mathrm{dH}$ ), strong presence of elements $\mathrm{Na}^{+}: 29,3-133,4 \mathrm{mg} / 1$, $\mathrm{Cl}^{-}: 56,7-241,1 \mathrm{mg} / 1, \mathrm{SO}_{4}^{2-}: 2,1-68,9 \mathrm{mg} / \mathrm{l}$, in places high concentrations on substances mainly anthropogenic origin as $\mathrm{NO}_{3}{ }^{-}: 13,6-67,0 \mathrm{mg} / 1, \mathrm{NH}_{4}{ }^{+}: 0,01-1,75 \mathrm{mg} / \mathrm{l}$ and $\mathrm{PO}_{4}{ }^{3-}: 0,03-0,36 \mathrm{mg} / \mathrm{l}$. The presence of all these elements reflects the varied geogenic and anthropogenic effects on the exploitation of aquifers. Concentrations, in the larger proportion of samples, exceed the upper permissible limits of Directive EE98 / 83 and declare unfit for human consummation. Based on the Piper diagram (Fig. 3) these waters are classified as geoalkaline/bicarbonate with a high proportion of alkali. In this category the dominant hydrochemical types are $\mathrm{Ca}-\mathrm{Mg}-\mathrm{Na}-\mathrm{HCO}_{3}-\mathrm{Cl}, \mathrm{Mg}-\mathrm{Ca}-\mathrm{Na}-$ $\mathrm{HCO}_{3}-\mathrm{Cl}$ and $\mathrm{Na}-\mathrm{Ca}-\mathrm{Cl}-\mathrm{HCO}_{3}$. Generally, in these waters there is no dominant anion or cation and indicate waters exhibiting mixing processes being in a hydrochemical evolution. Diagram Durov shows this evolution (Fig. 4). It is obvious that these waters come from a mixing process of different aquifers occurred in the loose Plio-Pleistocene sediments and the infiltrated water as well. The presence of high concentration of ions $\mathrm{Na}^{+}, \mathrm{Cl}^{-}$and $\mathrm{SO}_{4}{ }^{2-}$ is attributed to anthropogenic factors (fertilizers and pesticides) as well as the residual salts, as the Pliocene deposits of the region consist mainly of sediments of lacustrine and lagoon origin. In the diagram Hounslow (Hounslow, 1995) (Fig. 5) it is shown ionic ratios $\mathrm{Ca} / \mathrm{Ca}+\mathrm{SO}_{4}$ against $\mathrm{Na} / \mathrm{Na}+\mathrm{Cl}$ which finds that the higher percentage of the water samples is shown in the area of mixing waters. In particular, all samples from the aquifers of Neogene and Quaternary sediments are displayed in this area of the diagram. 
Table 1 - Statistical analysis of the results of chemicals analyses.

\begin{tabular}{|c|c|c|c|c|c|c|c|c|c|}
\hline \multirow[t]{2}{*}{ Parameter } & \multicolumn{3}{|c|}{$\begin{array}{c}\text { Springs } \\
\text { (Quaternary Deposits) } \\
\text { (3probe) }\end{array}$} & \multicolumn{3}{|c|}{$\begin{array}{c}\text { Boreholes } \\
\text { (Neocene sediments) } \\
\text { (11probe) }\end{array}$} & \multicolumn{3}{|c|}{$\begin{array}{c}\text { Boreholes } \\
\text { (Carbonate sediments) } \\
\text { (7probe) }\end{array}$} \\
\hline & $\min$ & $\max$ & aver. & $\min$ & $\max$ & aver. & $\min$ & $\max$ & aver. \\
\hline Temperature ${ }^{\circ} \mathrm{C}$ & 13.2 & 18.1 & 16.4 & 17.5 & 24.0 & 19.4 & 17.5 & 20.1 & 18.1 \\
\hline $\mathrm{pH}$ & 7.3 & 8.1 & 7.7 & 7.6 & 8.2 & 7.8 & 7.5 & 8.3 & 7.7 \\
\hline $\mathrm{EC} \mu \mathrm{S} / \mathrm{cm}$ & 463 & 698 & 591 & 612 & 1334 & 840 & 586 & 855 & 657 \\
\hline TDS mg/l & 487 & 562 & 531 & 580 & 974 & 699 & 527 & 660 & 602 \\
\hline Total Hard. ${ }^{\circ} \mathrm{dH}$ & 15.1 & 19.6 & 16.9 & 16.0 & 32.0 & 19.1 & 14.4 & 17.9 & 16.5 \\
\hline Carb. Hard. ${ }^{\circ} \mathrm{dH}$ & 14.6 & 16.8 & 15.7 & 12.8 & 18.0 & 14.9 & 12.8 & 16.2 & 14.3 \\
\hline Perm. Hard. ${ }^{\circ} \mathrm{dH}$ & 0.3 & 2.8 & 1.2 & 1.4 & 14.0 & 4.3 & 0.0 & 3.9 & 2.5 \\
\hline $\mathrm{Ca}^{2+} \mathrm{mg} / \mathrm{l}$ & 49.6 & 105.0 & 82.5 & 51.2 & 115.2 & 83.6 & 35.2 & 104.0 & 81.3 \\
\hline $\mathrm{Mg}^{2+} \mathrm{mg} / \mathrm{l}$ & 9.1 & 39.1 & 23.1 & 21.7 & 73.4 & 32.3 & 11.3 & 49.6 & 22.2 \\
\hline $\mathrm{Na}^{+} \mathrm{mg} / \mathrm{l}$ & 12.5 & 30.7 & 22.1 & 29.3 & 133.4 & 60.2 & 22.2 & 70.0 & 45.1 \\
\hline $\mathrm{K}^{+} \mathrm{mg} / \mathrm{l}$ & 1.5 & 2.0 & 1.7 & 0.3 & 12.0 & 3.5 & 0.3 & 11.4 & 3.6 \\
\hline $\mathrm{HCO}_{3}{ }^{-} \mathrm{mg} / \mathrm{l}$ & 317.2 & 366.0 & 341.7 & 280.6 & 390.4 & 325.1 & 280.6 & 353.8 & 311.1 \\
\hline $\mathrm{Cl}^{-} \mathrm{mg} / \mathrm{l}$ & 24.0 & 35.0 & 27.9 & 56.7 & 241.1 & 110.7 & 49.6 & 106.3 & 67.7 \\
\hline $\mathrm{SO}_{4}{ }^{2-} \mathrm{mg} / \mathrm{l}$ & 6.2 & 17.0 & 13.1 & 2.1 & 68.9 & 31.8 & 3.3 & 57.0 & 31.1 \\
\hline $\mathrm{NO}_{3}{ }^{-} \mathrm{mg} / \mathrm{l}$ & 1.6 & 22.0 & 9.2 & 13.6 & 67.0 & 29.9 & 8.0 & 41.3 & 25.0 \\
\hline $\mathrm{NH}_{4}{ }^{+} \mathrm{mg} / \mathrm{l}$ & 0.01 & 0.15 & 0.08 & 0.01 & 1.75 & 0.21 & 0.02 & 0.54 & 0.17 \\
\hline $\mathrm{PO}_{4}{ }^{3-} \mathrm{mg} / \mathrm{l}$ & 0.08 & 0.25 & 0.15 & 0.03 & 0.36 & 0.21 & 0.06 & 0.94 & 0.34 \\
\hline $\mathrm{SiO}_{2} \mathrm{mg} / \mathrm{l}$ & 29.0 & 29.0 & 29.0 & 13.1 & 55.8 & 22.7 & 9.3 & 37.0 & 18.9 \\
\hline Fe ppm & 0.007 & 0.112 & 0.046 & 0.001 & 0.125 & 0.075 & 0.001 & 0.262 & 0.110 \\
\hline Mn ppm & 0.001 & 0.035 & 0.020 & 0.001 & 0.132 & 0.047 & 0.001 & 0.160 & 0.060 \\
\hline Zn ppm & 0.014 & 0.032 & 0.024 & 0.018 & 0.149 & 0.116 & 0.038 & 0.440 & 0.195 \\
\hline Ni ppm & 0.001 & 0.011 & 0.007 & 0.001 & 0.029 & 0.009 & 0.001 & 0.631 & 0.127 \\
\hline $\mathrm{Cu} \mathrm{ppm}$ & 0.001 & 0.010 & 0.006 & 0.001 & 0.286 & 0.069 & 0.001 & 0.022 & 0.005 \\
\hline Cr ppm & 0.001 & 0.009 & 0.006 & 0.001 & 0.001 & 0.001 & 0.001 & 0.009 & 0.002 \\
\hline $\mathrm{Cd} \mathrm{ppm}$ & 0.009 & 0.011 & 0.010 & 0.001 & 0.014 & 0.005 & 0.001 & 0.022 & 0.005 \\
\hline Co ppm & 0.001 & 0.008 & 0.005 & 0.001 & 0.094 & 0.009 & 0.001 & 0.033 & 0.007 \\
\hline
\end{tabular}




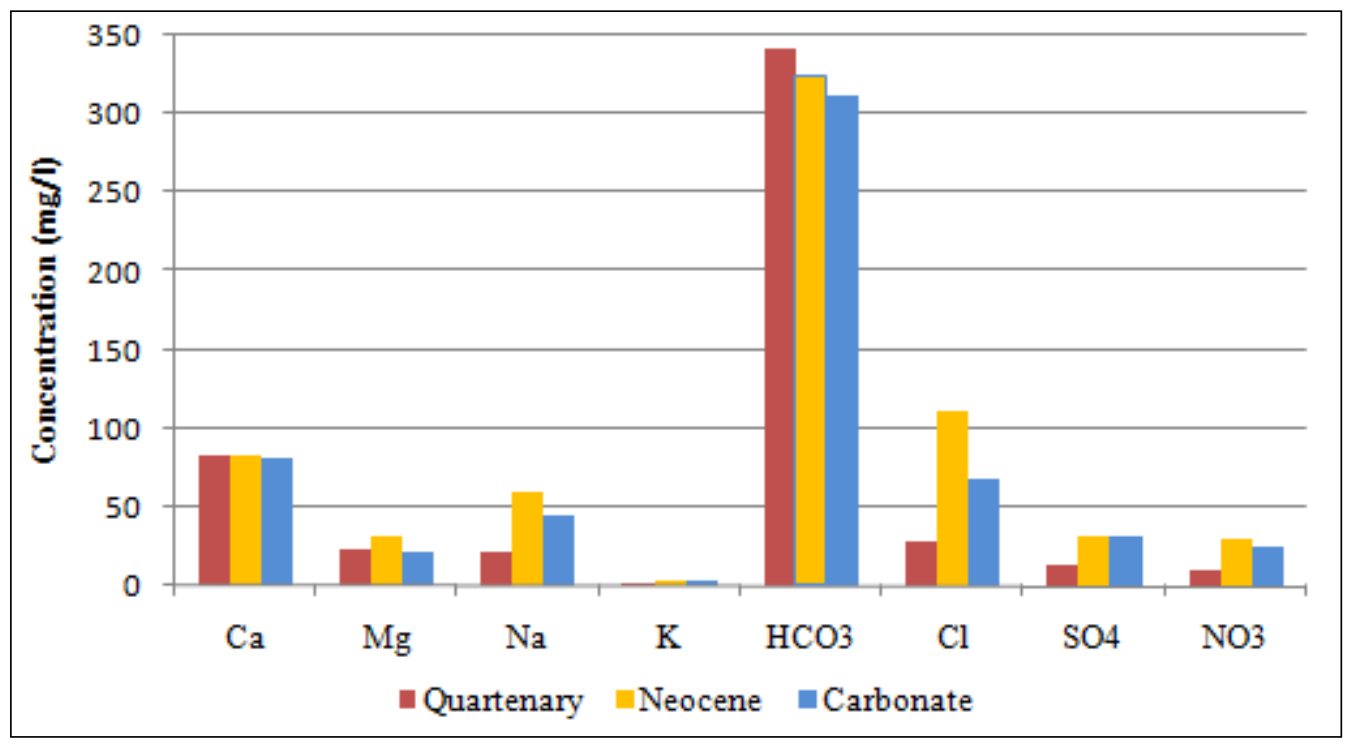

Figure 2 - Average values of the main elements from Quaternary, Neogene and carbonate aquifers of Vagia basin.

The water of the springs is mainly from low aquifer of Pleistocene sediments. They classified at the category of geoalkaline calcium-bicarbonate-waters and the hydrochemical type is $\mathrm{Ca}-\mathrm{HCO}_{3} \kappa \alpha l$ $\mathrm{Ca}-\mathrm{Mg}-\mathrm{HCO}_{3}$. In Durov diagram (Fig. 4) they are projected into the first field indicating fresh water from natural replenishment area. Comparing these waters with the pumping waters, the determined elements have lower concentration. Generally, they are slightly alkaline and do not show significant anthropogenic charges. The waters of the deep wells that exploit the karstic aquifer are classified at the category of geoalkaline-bicarbonate waters with a high percentage of alkali.

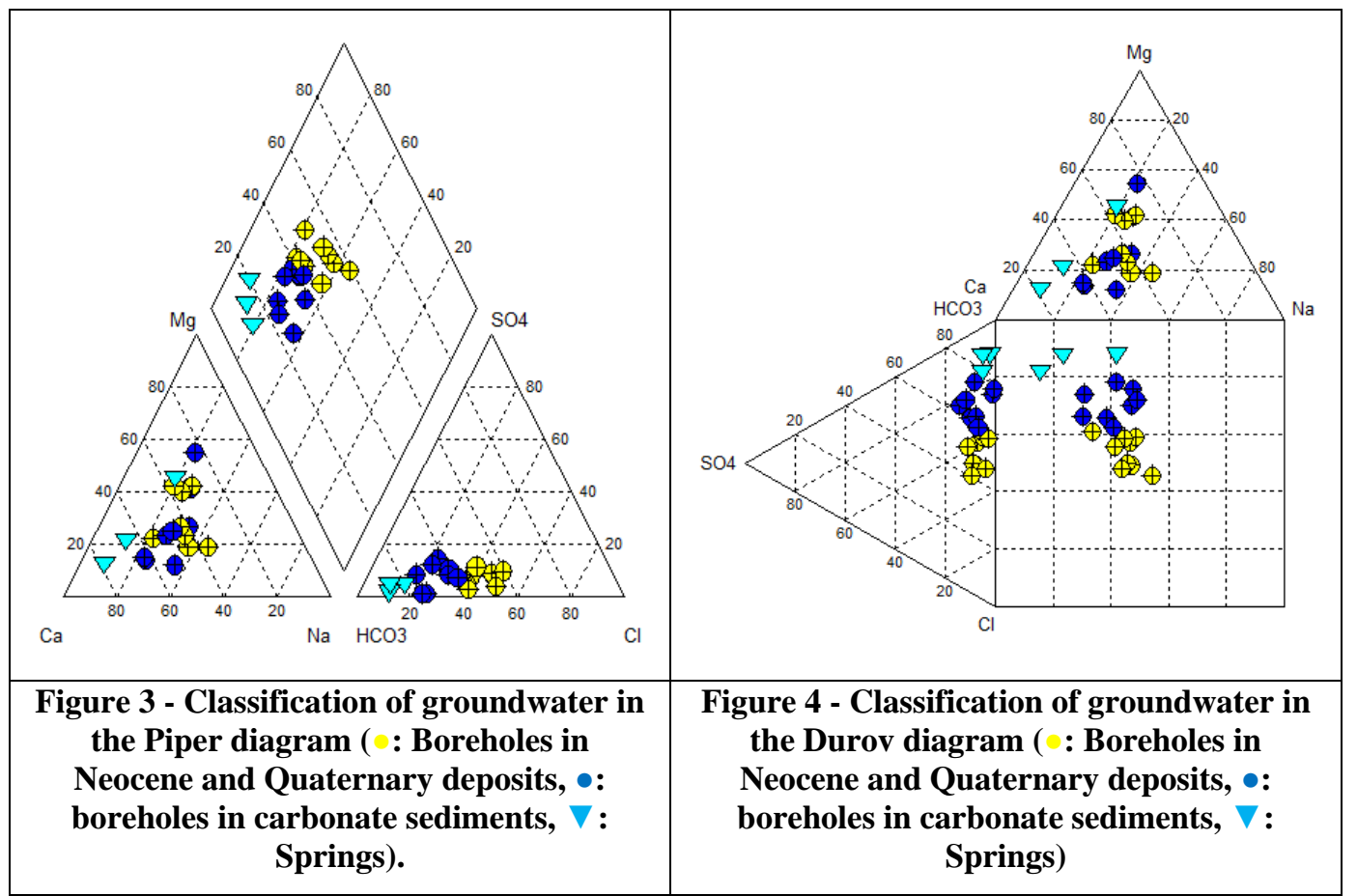


They show slightly alkaline nature and moderate hardness. The predominant hydrochemical types are $\mathrm{Ca}-\mathrm{Mg}-\mathrm{HCO}_{3}, \mathrm{Ca}-\mathrm{Mg}-\mathrm{Na}-\mathrm{HCO}_{3}-\mathrm{Cl}$ and $\mathrm{Mg}-\mathrm{Ca}-\mathrm{Na}-\mathrm{HCO}_{3}-\mathrm{Cl}$. The wide range of concentrations of ions $\mathrm{Na}^{+}: 22,2-70,0 \mathrm{mg} / 1, \mathrm{~K}^{+}: 0,3-11.4 \mathrm{mg} / 1, \mathrm{Cl}^{-}: 49,6-106,3 \mathrm{mg} / 1, \mathrm{SO}_{4}^{2-}: 3,3-57,0 \mathrm{mg} / 1, \mathrm{NO}_{3}^{-}: 8,0-$ $41,3 \mathrm{mg} / 1, \mathrm{NH}_{4}{ }^{+}: 0,02-0,54 \mathrm{mg} / 1$ and $\mathrm{PO}_{4}{ }^{3-}: 0,06-0,94 \mathrm{mg} / 1$ reflects the qualitative charge of carbonate aquifer. The presence of these compounds in carbonate water is attributed to the mixing of water from the upper Plio-Pleistocene sediments with the infiltrated water from surface through the sinkholes and generally the open karstic channels.

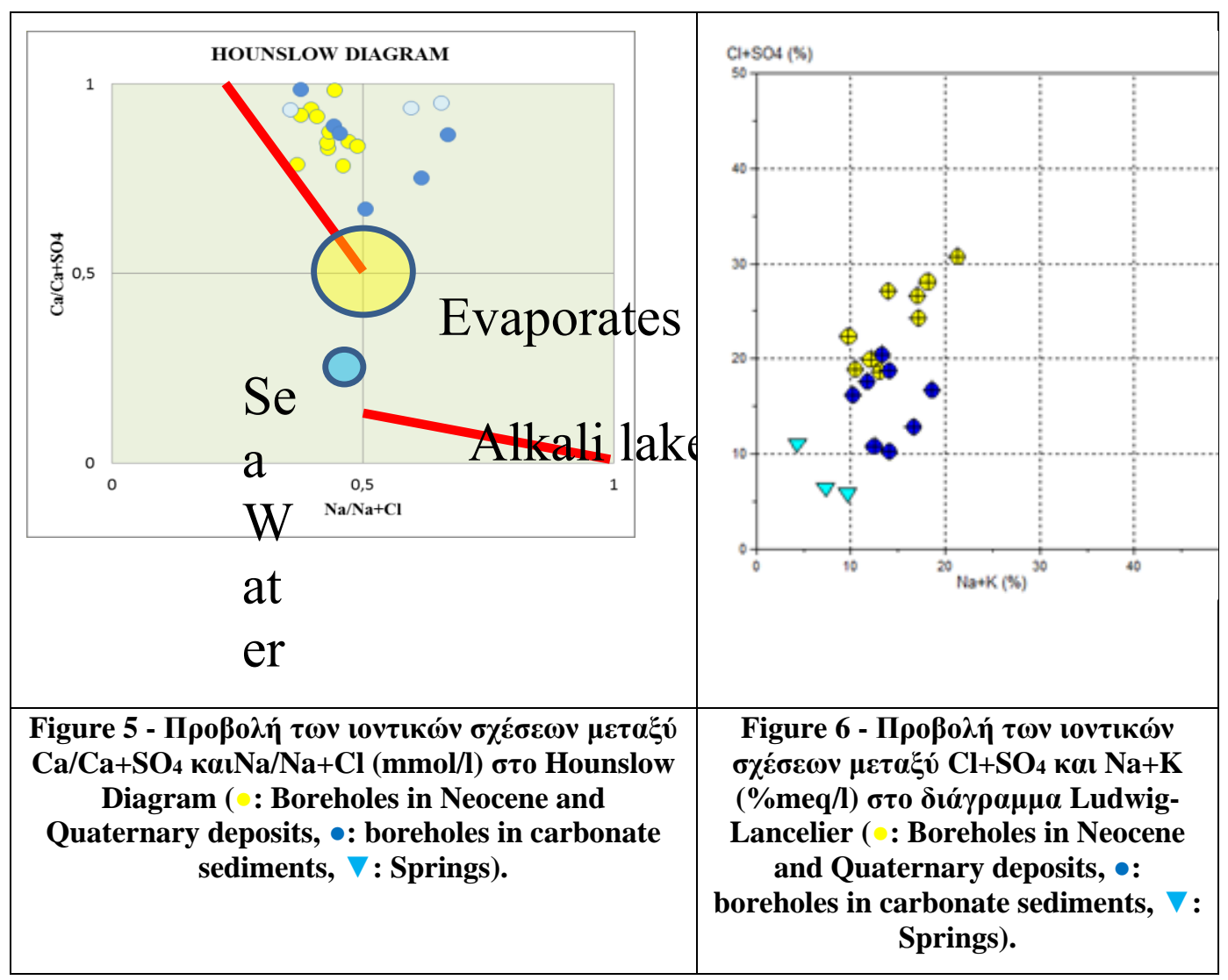

From the diagram Hounslow (Fig. 5) it is apparent that the qualitative differentiation of pumping water is affected by superficial factors as their points are projected into the field of mixing water, in the same way as the water of the wells that exploit the aquifers of the Plio-Pleistocene sediments are plotted. Similar observations are observed to arise from the diagram Ludwig-Langelier (Fig. 6) which shows the strong differentiation of the three qualitatively distinct groups of groundwater in the study area. According to the geochemical simulation of the groundwater Sylvite ( $\mathrm{KCl})$, Halite ( $\mathrm{NaCl})$, Anhydrite $\left(\mathrm{CaSO}_{4}\right)$, Quartz $\left(\mathrm{SiO}_{2}\right)$, Feldspar $\left(\mathrm{NaAlSi}_{3} \mathrm{O}_{8}\right)$, Dolomite $\left(\mathrm{CaMg}\left[\mathrm{HCO}_{3}\right]_{2}\right)$ and Calcite $\left(\mathrm{CaCO}_{3}\right)$ are the main minerals that participate in the rocks of the study area and are dissolv ed in groundwater. Characteristic of groundwater in the region is the presence of heavy metals which in many cases exceed the limits of the EU directives (EEC 98/83 1998) and WHO (1984) that concerns water for human use. Their presence into the water is attributed to geogenic and human factors due to intensive agriculture. The presence of shale-chert formation and ophiolites are the main feeder to heavy metals. It is likely, that the existence of Fe-Ni deposits in the underlying formations and in the wide area, feed the water with heavy metals. The higher values of concentrations are Fe: 0.001-0.262ppm, Mn: 0.001-0.132ppm, Zn: 0.014-0.440ppm, Ni: 0.001$0.631 \mathrm{ppm}$ and $\mathrm{Cu}$ : 0.001-0.286pm whereas the rest elements have very low values. 


\section{Conclusions}

The study of the hydrogeological conditions of the closed basin of Vagia concluded to the following:

- The study area is built up from two aquifer systems: the karstic one hosted in the autochthonous and the upper which is developed in the wide area, in clastic NeogeneQuaternary formations. The resources are significant and offer exploitation possibilities.

- Groundwater hosted in Neogene-Quaternary sediments is characterized by alkaline nature, medium to high hardness and high concentration of total dissolved solids. It is mixing water and indeterminate hydrochemical type, as the geochemical processes are in evolution. Predominant hydrochemical types are $\mathrm{Ca}-\mathrm{Mg}-\mathrm{Na}-\mathrm{HCO}_{3}-\mathrm{Cl}, \mathrm{Mg}-\mathrm{Ca}-\mathrm{Na}-\mathrm{HCO}_{3}-\mathrm{Cl}$ and $\mathrm{Na}-$ $\mathrm{Ca}-\mathrm{Cl}-\mathrm{HCO}_{3}$. The water quality shows anthropogenic effects, except individual cases. The found increased values of chloride, sodium and sulfates ions are attributed to the existence of residual salt. In places, there is a strong presence of anthropogenic origin compounds such as nitrate, ammonium and phosphate. The local presence of intense anthropogenic compounds and heavy metals make the use of such water unfit for human consumption.

- Karstic waters have slightly alkaline character and low concentrations of total salts. In places, present effects by surface water related to direct infiltration into the karstic mass by surface water through sinkholes and open karstic channels. Predominant hydrochemical types are $\mathrm{Ca}-\mathrm{HCO}_{3}$ and $\mathrm{Ca}-\mathrm{Mg}-\mathrm{HCO}_{3}$, except some samples that characterized $\mathrm{Ca}-\mathrm{Mg}-\mathrm{Na}-\mathrm{HCO} \mathrm{O}_{3}-\mathrm{Cl}$ and $\mathrm{Mg}-\mathrm{Ca}-\mathrm{Na}-\mathrm{HCO}_{3}-\mathrm{Cl}$, indicating water from overlaying aquifers. In places, dominate karstic waters of good quality that can be used for human consumption.

\section{References}

EEC 98/83, 1998. Council Directive 98/83/EC (Drinking Water Directive), European Commission, Brussels.

Davou, Ir., 2014. Hydrogeological - environmental research in basin of Vagia - Viotia, Postgraduate Thesis, Agricultural University of Athens, $175 \mathrm{pp}$.

Hounslow, A.W., 1995. Water quality data: Analysis and interpretation, Lewis Publishers, Boca Raton.

Pagounis, M., Gatsogianis, A. and Gertsos, Th., 1989. Hydrogeological map of Greece, Vagia Sheet, I.G.M.E.

Tataris, A., Kounis, G. and Maragkoudaki, N., 1970. Geological map of Greece, Vagia Sheet, I.G.S.R.

WHO, 1984. Guidelines for drinking-water quality, Vol. 2, Health criteria and other supporting information, Geneva. 